\title{
Analisis Penyebab Masyarakat Tetap Tinggal di Kawasan Rawan Bencana Gunung Merapi (Studi di Lereng Gunung Merapi Kecamatan Cangkringan, Kabupaten Sleman Daerah Istimewa Yogyakarta)
}

\author{
Dwi Rustiono Widodo*, Sutopo Purwo Nugroho, Donna Asteria \\ Environmental Science University of Indonesia \\ *) Author Correspondence. Hp: +628158821010. Email: dwi_rustiono@yahoo.com
}

\begin{abstract}
ABSTRAK
Penelitian ini bertujuan untuk memetakan faktor-faktor yang menyebabkan masyarakat tetap tinggal di Kawasan Rawan Bencana (KRB) III Gunung Merapi. Penelitian ini dilakukan dengan pendekatan mixed method. Penentuan jumlah responden dengan rumus Slovin dengan batas toleransi 7 persen dan terpilih sebanyak 151 responden. Analisis yang digunakan untuk mengetahui faktor-faktor yang menyebabkan masyarakat tetap tinggal di daerah rawan bencana menggunakan analisis deskriptif statistik. Hasil penelitian menunjukkan bahwa sebesar 61,6 persen masyarakat merasa nyaman dan tenteram tetap tinggal di daerahnya meski daerahnya rawan bencana. Kenyamanan ini dikarenakan faktor lingkungan, ekonomi, dan sosial. Faktor lingkungan terutama kesuburan tanah, potensi pasir, kerikil dan batu. Sebanyak 56,9 persen penduduknya berpenghasilan lebih besar dari upah minimum regional kabupaten yang sebesar 1,4 juta rupiah per bulan. Sebanyak 92,7 persen mereka mempunyai kerabat yang masih tinggal di satu lokasi dan 95,4 persen aktif dan ikut serta dalam kegiatan kemasyarakatan seperti arisan, pengajian, dan perkumpulan lainnya.
\end{abstract}

Kata kunci: Bencana, Erupsi, Kesiapsiagaan, Kawasan Rawan Bencana

English Title: Analysis the Causes That Make People Remain in Disaster Prone Area of Mount Merapi (Study in Mount Merapi Slope of Cangkringan Subdistrict, Sleman District, Yogyakarta Special Region

\begin{abstract}
This study aims to map the factors that cause people to stay in Disaster Prone Areas (KRB) III of Mount Merapi This research is conducted by mixed method approach. Determination the number of respondents carried out by Slovin formula with a tolerance limit of 7 percent and selected 151 respondents. Determination the factors that cause people to stay in disaster prone areas using descriptive analysis. The results showed that 61.6 percent of people feel comfortable and peaceful stay in their area despite the disaster-prone areas. This convenience is due to environmental, economic, and social factors. Environmental factors, especially soil fertility, the potential of sand, gravel, and stone. 56.9 percent of the population earns more than the district minimum wage of 1.4 million rupiahs per month. About 92.7 percent of them have relatives who still live in one location and 95.4 percent active and participate in community activities such as arisan, pengajian, and other associations.
\end{abstract}

Keywords: Disaster, Eruption, Preparedness, Disaster prone area

Citation: Widodo, D.R., Nugroho, S.P, dan Asteria, D. (2017). Analisis Penyebab Masyarakat Tetap Tinggal di Kawasan Rawan Bencana Gunung Merapi (Studi di Lereng Gunung Merapi Kecamatan Cangkringan, Kabupaten Sleman Daerah Istimewa Yogyakarta). Jurnal Ilmu Lingkungan, 15(2),135-142, doi:10.14710/jil.15.2.135-142

\section{Pendahuluan}

Indonesia adalah salah satu negara dengan jumlah gunung api aktif terbanyak di dunia. Gunung apigunung api ini merupakan bagian dari rangkaian pegunungan api aktif yang dikenal dengan sebutan ring of fire (Rijanta et al., 2014). Dalam rekaman sejarah gunung api di dunia, tercatat 2 letusan besar terjadi di Indonesia, yaitu letusan Gunung Tambora dan Gunung Krakatau. Letusan Gunung Tambora pada tahun 1815 mengakibatkan tersebarnya abu vulkanik di seluruh muka bumi. Dampak lainnya, pada tahun 1816 terjadi penurunan temperatur rerata bumi 1 derajat. Sejak itu, pada tahun 1816 dikenal sebagai tahun tanpa musim panas di belahan 
bumi utara. Gunung Krakatau yang meletus pada bulan Agustus 1883, memiliki dampak yang terkenal di seluruh dunia. Awan debunya melintasi dunia beberapa kali dan kejadian tersebut memicu tsunami yang mampu mendorong kapal-kapal perang ratusan meter ke daratan (Davidson \& Da Silva, 2000; Pratomo \& Abdurachman, 2004; Mawardi, 2006).

Sementara itu, salah satu gunung api di Indonesia yang paling sering meletus adalah Gunung Merapi. Gunung ini aktif sejak tahun 1900 sampai dengan sekarang dengan periode diam atau istirahat yang pendek (rata- rata tidak lebih dari 3,5 tahun). Sebagai pembanding Gunung Kelud di Jawa Timur mempunyai siklus letusan 15 tahun sekali (Voight et al., 2000). Gunung Merapi diketahui memiliki siklus erupsi selama 3,5 tahun sekali, akan tetapi siklus tersebut hanyalah hitungan secara statistik. Jadi, erupsi Gunung Merapi sebanyak lebih dari 100 kali tersebut kisaran erupsi bisa terjadi dalam waktu 1 sampai 18 tahun. Artinya, erupsi Gunung Merapi dalam satu atau dua tahun sekali itu juga dapat terjadi. Singkatnya, erupsi Gunung Merapi merupakan ancaman bencana yang bersifat permanen (Subandriyo, 2012).

Meski banyak menimbulkan bencana, penduduk yang hidup dan bekerja sehari-hari di daerah yang berisiko terhadap bahaya awan panas semakin banyak. Penduduk yang menghuni Kawasan Rawan Bencana III (KRB III) yaitu daerah-daerah yang secara historis terpengaruh aliran piroklastik dan Kawasan Rawan Bencana II (KRB II) sebagai daerah yang masih dapat dicapai oleh jatuhan bahan-bahan lepas seperti bom dan lapili terus meningkat. Pada tahun 1976 jumlah penduduk di KRB III 40.800 jiwa, sedangkan di KRB II sebesar 72.600 jiwa. Pada tahun 1995 meningkat menjadi 79.100 jiwa di KRB III dan 114.800 jiwa di KRB II (Alzwar et al., 1988; Thouret et al., 2000). Hingga tahun 2010 sebelum terjadi erupsi besar, jumlah penduduk di Kawasan itu kurang lebih 100 ribu jiwa di KRB III dan 140 ribu jiwa di KRB II (BPS, 2010).

Kecamatan Cangkringan Kabupaten Sleman juga masuk ke dalam tiga kawasan tersebut, yakni KRB I, KRB II dan KRB III. Pemerintah Kabupaten Sleman telah menetapkan 9 dusun di kawasan Kabupaten Sleman sebagai Kawasan Rawan Bencana III yang tidak layak digunakan sebagai daerah permukiman, namun kawasan ini tetap saja masih dihuni. Pasca letusan Gunung Merapi pada tahun 2010 tidak menyurutkan masyarakatnya untuk tetap tinggal di daerah tersebut.

Erupsi Merapi pada tahun 2010 tepatnya di bulan Oktober, mengakibatkan 367 orang meninggal, lebih dari 2.300 rumah rusak, lebih dari 400.000 orang dievakuasi dan ribuan hektar lahan pertanian rusak hingga mencapai kerugian dan kerusakan Rp 3,5 trillun (BAPPENAS dan BNPB, 2011).

Pada tahun 2011, pasca erupsi Gunung Merapi, pemerintah menyusun Rencana Aksi Nasional Rehabilitasi dan Rekonstruksi Pasca Bencana Erupsi Gunung Merapi Provinsi Daerah Istimewa 136
Yogyakarta dan Jawa Tengah 2011-2013 (BAPPENAS dan BNPB, 2011). Rencana Aksi Nasional Rehabilitasi dan Rekonstruksi tersebut memuat kebijakan relokasi bagi masyarakat lereng Gunung Merapi. Kebijakan relokasi didasari oleh peta Kawasan Rawan Bencana (KRB) Gunung Merapi yang dikeluarkan oleh Pusat Vulkanologi dan Mitigasi Bencana Geologi, Kementrian Energi dan Sumber Daya Mineral (ESDM). Peta ini dibuat setelah melalui evaluasi untuk mendapatkan perubahan besar yang terjadi pada morfologi Gunung Merapi pasca letusan 2010. Pemetaan daerah rawan bencana ini sangat dinamis. Peta daerah bahaya Gunung Merapi sejak pertama kali dibuat oleh Stehn pada tahun 1935, telah direvisi lima kali, mengikuti dinamika letusan yang berubah-ubah dari sisi besaran letusan, tipe letusan, sebaran letusan, dan jangkauan letusan (Yusup, 2014).

Berdasarkan ketentuan tersebut, maka masyarakat yang tinggal di KRB III Gunung Merapi diharuskan untuk relokasi. Terdapat 3.612 Kepala Keluarga (KK) di Jawa Tengah dan Daerah Istimewa Yogyakarta yang memerlukan relokasi ke tempat yang lebih aman (Ni'am, 2014), baik dari ancaman erupsi maupun lahar dingin Gunung Merapi.

Sebanyak 9 dusun ditetapkan berada di KRB III yang meliputi Dusun Palemsari dan Pangukrejo di Desa Umbulharjo; Dusun Kaliadem, Petung, Jambu, dan Kopeng di Desa Kepuharjo; Dusun Kalitengah Lor, Kalitengah Kidul, dan Srunen di Desa Glagahharjo. Namun, ada tiga dusun diantaranya menolak untuk direlokasi. Ketiga dusun tersebut adalah Dusun Kalitengah Lor, Kalitengah Kidul dan Srunen yang semuanya berlokasi di Desa Glagaharjo (Herianto et al., 2012). Saat ini jumlah penduduk di ketiga dusun tersebut 1.317 jiwa, yang terdiri atas Dusun Kalitengah Lor 506 jiwa, Kalitengah Kidul 336 jiwa, dan Srunen 475 Jiwa (Monografi Desa 2016).

KRB III Gunung Merapi adalah kawasan yang letaknya dekat dengan sumber bahaya yang sering terlanda awan panas, aliran lava, guguran batu, lontaran batu (pijar) dan hujan abu lebat. Oleh karena tingkat kerawanan yang tinggi, maka kawasan ini tidak diperkenankan untuk digunakan sebagai hunian tetap. Namun, di kawasan tersebut masih ada sebagian penduduk yang tidak mau direlokasi dan tetap tinggal dan menetap, sehingga diperlukan analisis mengenai faktor-faktor yang menyebabkan penduduk untuk tetap tinggal di daerah rawan bencana diantaranya faktor ekonomi, sosial, dan lingkungan. Tujuan dari penelitian ini adalah untuk melihat kondisi lingkungan, ekonomi dan sosial budaya yang menyebabkan masyarakat memilih tetap tinggal di KRB.

\section{Metode Penelitian}

Penelitian ini menggunakan pendekatan kuantitatif dengan dua metode yaitu kuantitatif dan kualitatif. Lokasi penelitian berada di Dusun Kalitengah Lor, Kalitengah Kidul dan Srunen Desa Glagaharjo, Kecamatan Cangkringan, Kabupaten Sleman. 
Populasi dalam penelitian ini adalah Kepala Keluarga di Dusun Kalitengah Lor, Kalitengah Kidul, dan Srunen Kecamatan Cangkringan yang tinggal di daerah kawasan rawan bencana Gunung Merapi yang meliputi KRB III. Berdasarkan data Kepala Keluarga (KK) desa, jumlah KK dari ketiga dusun tersebut adalah $421 \mathrm{KK}$ yang terdiri atas Dusun Kalitengah Lor 192 KK, Kalitengah kidul 106 KK dan Srunen 143 KK. Metode yang digunakan untuk menentukan jumlah sampel adalah menggunakan rumus Slovin dengan batas toleransi kesalahan $7 \%$.

Untuk menghindari kesalahan ketika pengisian data, terdapat konten kuesioner yang tidak terdata, dan kesalahan lainnya maka jumlah sampel responden ditambah $10 \%$. Jumlah sampel terpilih sebanyak 151 yang disebar di ketiga dusun. Pembagian sampel KK dibagi secara proporsional pada setiap Rumah Tangga di ketiga dusun tersebut. Jadi jumlah sampel yang terpilih adalah Dusun Kalitengah Lor 68 KK, Kalitengah Kidul 38 KK dan Srunen 43 KK. Penentuan responden untuk kepala keluarganya dengan menggunakan systematic random sampling.

Dalam operasionalisasinya pengumpulan data secara kuantitatif tadi dilakukan melalui pertanyaan yang terstruktur berupa kuesioner. Kuesioner ini dibagikan dan ditanyakan langsung kepada targettarget kelompok yang disebut responden. Sedangkan untuk data kualitatif, didapat melalui wawancara mendalam dengan beberapa tokoh dan perangkat desa menggunakan panduan wawancara terutama untuk mengetahui faktor-faktor yang menyebabkan masyarakat tetap tinggal di daerah rawan bencana terutama faktor lingkungan, faktor sosial dan faktor ekonomi.

\section{Hasil danPembahasan}

\subsection{Kerentanan dan keterpaparan}

Dusun Kalitengah Lor, Kalitengah Kidul dan Srunen adalah dusun yang berada di Desa Glagaharjo. Ketiga dusun ini berada di wilayah Kawasan Rawan Bencana III Gunung Merapi, sehingga memiliki tingkat kerawanan bahaya cukup tinggi. Kerawanan itu dapat dilihat dari perubahan morfologi Gunung Merapi (gambar 1 dan gambar 2). Dari gambar tersebut terlihat jelas bahwa jika Gunung Merapi meletus arah aliran lava dan awan panas (Wedus Gembel) akan menuju ke tiga dusun tersebut. Ada $431 \mathrm{KK}$ dengan total jumlah penduduk 1.317 jiwa yang terancam jiwanya dari bahaya erupsi Gunung Merapi (Pemerintah Desa Glagaharjo, 2016).
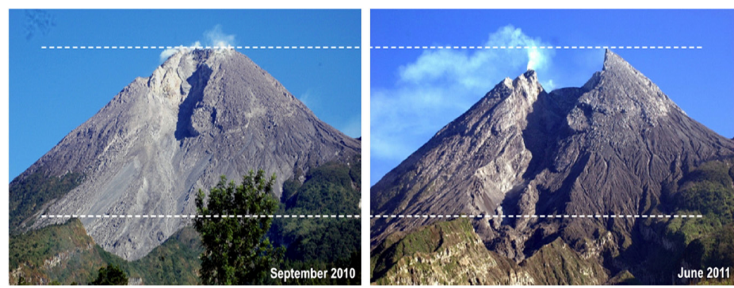

Gambar 1 Perubahan morfologi puncak Gunung Merapi (Sumber: Surono, 2012)

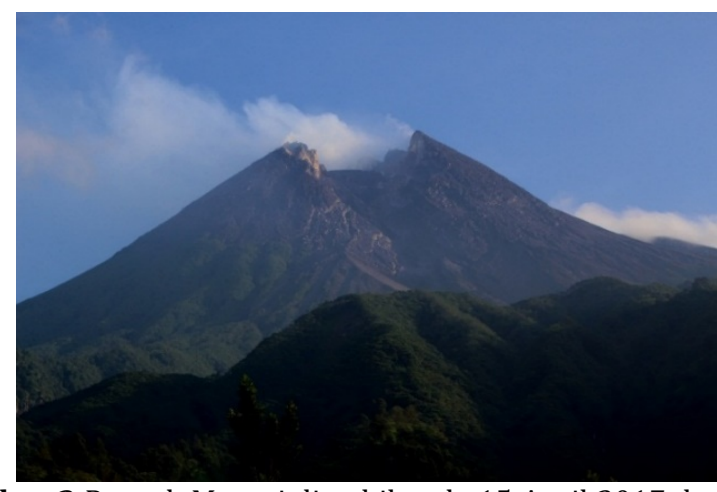

Gambar 2 Puncak Merapi diambil pada 15 April 2017 dar lokasi penelitian (Sumber: Dokumentasi peneliti 2017).

Ditinjau dari Tingkat pendidikan, di ketiga dusun tersebut masih tergolong rendah yaitu sebesar 33,5 persen tidak tamat SD sampai tamat SD, bahkan masih ada yang butu huruf sebesar 23,1 persen. Dusun yang mempunyai penduduk buta huruf terbanyak berada di Dusun Kalitengah Lor yaitu sebesar 48,4 persen. Dusun ini terletak paling ujung dan dekat dengan puncak Gunung Merapi.

Sebagian besar masyarakat di ketiga dusun ini bermatapencaharian sebagai petani dan peternak. Jumlah petani ada sekitar 40,3 persen dan peternak sebesar 38,9 persen. Jenis tanaman pada umumnya adalah jagung, ketela pohon, ketela rambat, kacang tanah, sayur-sayuran dan buah-buahan. Untuk tanaman perdagangan atau komoditi berupa tanaman cengkeh, pala/lada, tembakau, kelapa, kopi, dan coklat. Sementara itu untuk peternakan sebagian masyarakat beternak sapi baik berupa sapi perah dan sapi potong. Ternak lainnya adalah kambing dan ayam baik ayam buras maupun ayam ras potong.

Ditinjau dari segi usia penduduk, mayoritas penduduk di daerah penelitian berusia 56 tahun ke atas yaitu sebesar 38,3 persen atau penduduk pada usia tua, di mana tertinggi berada di Dusun Kalitengah Kidul yaitu sebesar 55,4 persen.

Dari uraian di atas dapat disimpulkan bahwa tingkat kerentanan dan keterpaparan penduduk terhadap bahaya letusan Gunung Merapi cukup tinggi. Hal ini ditandai oleh dominasi penduduk yang bermatapencaharian sangat tergantung dengan alam, mayoritas penduduk berpendidikan rendah bahkan tidak sekolah dan kelompok usia rentan (balita dan usia diatas 56 tahun) cukup tinggi. Seperti yang didefinisikan oleh United Nations International Strategy for Disaster Reduction (UNISDR, 2011) kerentanan sebagai karakteristik dan kondisi dari sebuah masyarakat, sistem, atau aset yang rentan terhadap efek merusak dari bahaya, sedangkan keterpaparan adalah penduduk, properti, sistem, atau elemen lainnya yang berada di wilayah bahaya yang berpotensi mengalami kerugian.

\subsection{Penolakan Relokasi}

Pemerintah telah berusaha untuk merelokasi permukiman warga yang berada di KRB III ke daerah bawahnya yang lebih aman. Namun, semua usulan 
dan opsi untuk relokasi itu ditolak oleh sebagian warga terutama di Dusun Kalitengah Lor, Kalitengah Kidul, dan Srunen. Penolakan relokasi ini juga terungkap dan mewakili semangat perlawanan yang diinspirasi kebijakan lokal (local wisdom) yaitu "sedumuk bathuk senyari bumi" yang artinya sejengkal tanah yang dimiliki akan dipertahanakan selamanya karena merupakan tanah kelahiran dan tanah yang dimiliki merupakan hak milik masyarakat, oleh karena itu akan tetap dipertahankan. Masyarakat di ketiga dusun tersebut juga mempunyai cara pandang tersendiri bahwa antara ancaman dan sumber kehidupan telah menyatu dalam kehidupan dan penghidupan masyarakat (living harmony with risk disaster), berbeda dengan pemerintah yang menggunakan tindakan preventif dengan cara menjauhi bencana terlebih dahulu baru meningkatkan kesipasiagaan di tempat yang lebih aman. Aksi penolakan yang dilakukan masyarakat akan berdampak buruk, sebab kawah Gunung Merapi kini sudah terbuka mengarah ke selatan tenggara yakni ke Desa Glagaharjo.

Menurut salah satu informan yaitu kepala Desa Glagaharjo, Suroto, yang bertempat tinggal di Dusun Kalitengah Kidul, bahwa awal 2011 saat sebagian warga masih tinggal di rumah-rumah sementara (huntara), ada upaya pemulihan yang dilakukan pemerintah terutama bagi warga yang rumahnya berada pada KRB III dan rumahnya rusak akibat erupsi Merapi.

Pada saat itu pemerintah merencanakan akan membangunkan rumah (huntap) bagi warga korban erupsi di lokasi yang baru. Sosialisasi sudah mulai dilakukan ke warga-warga yang berada di pengungsian maupun di huntara. Warga yang rumahnya berada di KRB III mulai gelisah dengan informasi simpang siur terhadap nasib tanah hunian mereka. Selama di pengungsian mereka diskusi dan bermusyawarah sehingga berujung pada diambilnya keputusan secara bulat bahwa mereka satu dusun, kompak tidak mau direlokasi.

Persoalan lainnya adalah mayoritas warga dusun Kalitengah Lor, Kalitengah Kidul dan Srunen memang memiliki rumah dan lahan pertanian yang cukup luas dibandingkan dengan apa yang ditawarkan pemerintah dalam bentuk pemberian huntap per KK. Tanah yang luas, dengan rumah dan sekitarnya berupa pekarangan yang dimanfaatkan sebagian untuk halaman, tanaman hortikultura dan kandang sapi menjadi pemikiran warga. Tanah itu merupakan warisan dari orang tua mereka, dan merekapun berpikir bahwa tanahnya kelak akan diwariskan ke anak cucunya.

Luas huntap yang dibagikan kepada warga korban erupsi berupa tanah 100 meter dengan bangunan rumah seluas $36 \mathrm{~m} 2$. Luas tanah dan bangunan yang tidak seberapa itu bila dibandingkan dengan besar/luas rata-rata rumah warga sebelumnya menjadi alasan lainnya warga tidak mau pindah ke huntap.
Warga juga berat meninggalkan tanah kelahirannya, sebanyak 92,1 persen responden menyatakan sejak lahir mereka sudah tinggal di dusun tersebut turun temurun, sehingga untuk meninggalkan tanah kelahiran dan membangun kehidupan di tempat lain dirasa sangat berat oleh warga.

Penolakan relokasi ini juga tercermin dari hasil survei peneliti. Sebanyak 95,4 persen responden menyatakan tidak ingin pindah ke tempat lain. Warga berpendapat bahwa tanah hasil erupsi Merapi dapat mendatangkan kesuburan yang berdampak pada sumber pendapatan ekonomi mereka.

Dari hasil survei tampak bahwa rasa nyaman dan tenteram merupakan alasan utama masyarakat untuk tetap hidup dan tinggal di daerah rawan bencana yaitu sebesar 61,6 persen. Seperti yang diutarakan Magnis Suseno dalam bukunya Etika Jawa (2003), nyaman dan tenteram atau dalam bahasa Jawanya ayem tentrem adalah keadaan keselarasan antara makrokosmos (jagad gedhe) dan mikrokosmos (jagad cilik). Orang Jawa memandang penting bahwa seseorang harus pada posisi tempat yang tepat. Kosmos adalah suatu keseluruhan teratur dimana setiap unsur mempunyai tempatnya yang tepat dan selama unsur-unsur tersebut berada pada tempatnya yang tepat maka akan tercipta ketenangan dan dunia akan aman.

Tabel 1. Alasan masyarakat tidak ingin pindah ke tempat lain

\begin{tabular}{lcc}
\hline Alasan & Jumlah & Persen \\
\hline Nyaman dan tenteram & 93 & 61,6 \\
Sejak lahir/tanah kelahiran & 9 & 6,0 \\
Ekonomi/pekerjaan & 47 & 31,1 \\
lainnya & 2 & 1,3 \\
Total & 151 & 100,0 \\
\hline
\end{tabular}

Sumber: Hasil survey 2017

Bagi orang jawa struktur keseluruhan dari masyarakat, alam dan alam adikodrati tercipta dalam keadaan selaras dan harmonis. Selain dirinya sendiri, segala yang ada dalam struktur keseluruhan kosmos dihayati sebagai hidup, berhayat dan berjiwa. Oleh sebab itu, manusia jawa dalam kehidupannya harus selalu mengembangkan sikap rukun dan hormat terhadap dirinya sendiri, sesama manusia, alam, dan alam adikorati, demi terjaganya kesatuan dan keselarasan kosmos. Sikap rukun dan hormat ini diekspresikan dalam bentuk bahwa dalam segala situasi hendaknya ia bersikap sedemikian rupa sehingga sesuai dengan posisinya, baik yang horizontal maupun vertikal sehingga tidak menimbulkan konflik baik bagi batinnya sendiri, sesamanya, alam, maupun alam adikodrati. Hal inilah yang dirasakan penduduk yang tinggal di lereng Merapi yang merasa nyaman atau ayem nyanding 
Widodo, D.R., Nugroho, S.P, dan Asteria, D. (2017). Analisis Penyebab Masyarakat Tetap Tinggal di Kawasan Rawan Bencana Gunung Merapi (Studi di Lereng Gunung Merapi Kecamatan Cangkringan, Kabupaten Sleman Daerah Istimewa Yogyakarta). Jurnal Ilmu Lingkungan, 15(2),135-142, doi:10.14710/jil.15.2.135-142

Merapi atau hidup nyaman bersanding Gunung Merapi (Triyoga, 2010).

\subsection{Faktor-faktor yang Menyebabkan Masyarakat Tetap Tinggal di Kawasan Rawan Bencana.}

Kelman dan Mather (2008) menunjukkan bagaimana peluang vulkanik dapat digunakan untuk mata pencaharian yang berkelanjutan. Pendekatan penghidupan yang berkelanjutan untuk gunung berapi adalah memaksimalkan manfaat lingkungan vulkanik bagi masyarakat, terutama selama periode diam. Mendukung pendekatan penghidupan yang berkelanjutan, dan memperoleh manfaat dari sumber daya fisik (misalnya, pertambangan), sumber daya energi (misalnya, panas), dan sumber daya sosial (misalnya, pariwisata) seperti yang diungkapkan Sigurdsson (2000). Selain faktor lingkungan yang dapat menjadi penghidupan berkelanjutan, faktor sosial dan faktor ekonomi di daerah penelitian juga menyebabkan masyarakat enggan meninggalkan tanah kelahirannya.

\subsubsection{Faktor Lingkungan}

Hasil analisis kandungan mineral dalam abu dan pasir vulkan letusan Gunung Merapi 2010 yang dilakukan di jurusan Tanah Fakultas Pertanian UGM (Nuryani, 2011). Dari hasil analisis menunjukkan bahwa kualitas abu cukup baik, namun perlu pembilasan yang cukup untuk menghilangkan garam terlarutkan yang berupa kation basa, aluminium dengan anion sulfat dan klorida. Abu vulkan juga mengandung unsur yang bermanfaat bagi tanaman, kandungan unsur hara didominasi oleh silika sebesar $54 \%$.

Selain itu, kesuburan tanah itu juga dimanfaatkan untuk, hijauan pakan yang telah dikenal petani/peternak antara lain rumput gajah (Pennisetum purpureum), rumput Raja (Pennisetum purpuroides), Panicum maximum dan Brachiaria decumbes. Jenis tanaman pekan tersebut telah menjadi pakan utama sapi perah maupun sapi potong di kawasan Merapi karena produksi dan kualitasnya yang tinggi. Produksi bahan kering hijauan rumput tersebut dapat mencapai $40-110$ ton/ha/th (Purwantari et al., 2012).

Hampir separuh responden di daerah penelitian mempunyai ternak sapi. Rata-rata tiap rumah tangga mempunyai ternak sapi baik sapi potong maupun sapi perah antara 2-4 ekor. Ada 6 persen responden yang bermatapencaharian sebagai peternak dan sebanyak 39,5 persen beternak adalah matapencaharian sampingan. Bahkan boleh dikatakan beternak sapi merupakan tabungan jika sewaktu-waktu membutuhkan dana. Produksi sapi perah rata-rata 1 bulan menghasilkan 15 liter susu dengan harga satu liter Rp 70.000,-, sedangkan untuk sapi potong biasanya masyarakat memanen setelah usia sapi berkisar 1,5-2,5 tahun dengan rata-rata menjual harga satu ekor sapi berkisar antara 13-15 juta rupiah, tergantung bobot sapi tersebut.
Di Dusun Kalitengah Lor dan Kalitengah Kidul sapi yang dipelihara oleh warga didominasi oleh sapi potong. Ada 67 peternak sapi potong di Kalitengah Lor dan 40 peternak di Kalitengah Kidul, sedangkan untuk sapi perah ada 15 peternak di Kalitengah Lor dan 4 peternak di Kalitengah Kidul.

Selain kesuburan tanah, potensi pasir dan batu yang mencapai 140 juta meter kubik dan tersebar di puncak, lereng, kawasan kaki gunung dan sejumlah sungai yang berhulu di Merapi (Wacano, 2014) adalah sumber daya mineral lainnya. Material letusan sebesar 35 juta meter kubik juga mengisi alur Sungai Gendol sejauh $15 \mathrm{~km}$. Alur Sungai Gendol merupakan salah satu lembah yang terisi oleh material letusan Gunung api Merapi tahun 2010. Material piroklastik alur Sungai Gendol berasal dari rangkaian letusan tanggal 4-5 November 2010. Puncak letusan terjadi tanggal 4 November 2010 pukul 17:05 WIB (Surono et al., 2012). Puncak letusan menyebabkan runtuhnya kubah lava di bagian kawah. Sungai Gendol merupakan sungai yang berbatasan dengan daerah penelitian.

Dari hasil survei, sebanyak 12,6 persen masyarakat di ketiga dusun tersebut bermatapencaharian pokok sebagai penambang dan 24,4 persen menyatakan menambang pasir merupakan pekerjaan sampingan selain sebagai petani maupun peternak. Rata-rata pendapatan sehari selama menambang pasir berkisar Rp 70.000,sampai Rp 100.000,-.

Kegiatan penambangan dalam jangka pendek memang memberikan keuntungan dari berbagai sisi, antara lain kapasitas alur sungai menjadi normal, pendapatan ekonomi penduduk lokal naik, serta pendapatan daerah mulai dari tingkat desa, kecamatan, dan kabupaten juga meningkat. BPS Sleman, (2015) melaporkan selama tahun 20102014, pertumbuhan kontribusi terbesar dalam pembentukan PDRB atas dasar harga berlaku diberikan oleh sektor pertambangan dan penggalian sebesar $11,6 \%$.

\subsubsection{Faktor Sosial}

\subsubsection{Tingkat Pendidikan}

Tingkat pendidikan yang dimiliki oleh seseorang sangat mempengaruhi cara berfikir seseorang dalam berbagai hal. Seperti yang dikemukakan oleh Macchi dalam Himbawan (2010), bahwasannya mereka yang tingkat pendidikannya lebih tinggi tidak akan rentan terhadap bencana dibandingkan mereka yang pendidikannya lebih rendah, hal ini dikarenakan tingkat pendidikan akan berhubungan dengan pekerjaan seseorang, orang yang tingkat pendidikannya tinggi cenderung pekerjaannya mapan dan tentunya akan berhubungan pula dengan tingkat pendapatannya yang tinggi, sebaliknya seseorang yang pendidikannya rendah cenderung mendapatkan pekerjaan yang tidak bagus dan pendapatannya juga rendah. 
Tabel 2. Tingkat pendidikan responden

\begin{tabular}{cccccccccc}
\hline Pendidikan & \multicolumn{2}{c}{ Kalitengah Lor } & \multicolumn{2}{c}{ Kalitengah Kidul } & \multicolumn{2}{c}{ Srunen } & \multicolumn{2}{c}{ Total } \\
\cline { 2 - 10 } & Jumlah & $\%$ & Jumlah & $\%$ & Jumlah & $\%$ & Jumlah & $\%$ \\
\hline Tidak sekolah & 23 & 33,8 & 5 & 12,8 & 0 & 0,0 & 28 & 18,5 \\
Tidak tamat SD & 11 & 16,2 & 14 & 35,9 & 2 & 4,5 & 27 & 17,9 \\
Tamat SD/sedrajad & 29 & 42,6 & 12 & 30,8 & 24 & 54,5 & 65 & 43,0 \\
Tamat SMP/Sedrajad & 2 & 2,9 & 4 & 10,3 & 7 & 15,9 & 13 & 8,6 \\
Tamat SMA/sedrajad & 3 & 4,4 & 2 & 5,1 & 6 & 13,6 & 11 & 7,3 \\
Tamat Diploma & 0 & 0,0 & 0 & 0,0 & 4 & 9,1 & 4 & 2,6 \\
\hline
\end{tabular}

Tabel 3. Keikutsertaan responden dalam organisasi

\begin{tabular}{crrrr}
\hline \multirow{2}{*}{$\begin{array}{c}\text { Ikut menjadi anggota } \\
\text { organisasi }\end{array}$} & $\begin{array}{c}\text { Dusun } \\
\text { Kalitengah } \\
\text { Lor (\%) }\end{array}$ & $\begin{array}{c}\text { Kalitengah } \\
\text { Kidul (\%) }\end{array}$ & $\begin{array}{c}\text { Srunen } \\
(\%)\end{array}$ & $\begin{array}{c}\text { Total } \\
(\%)\end{array}$ \\
\hline Ya & 94,1 & 92,3 & 100 & 95,4 \\
Tidak & 5,9 & 7,7 & 0,0 & 4,6 \\
Total & 100 & 100 & 100 & 100 \\
\hline
\end{tabular}

Sumber: Hasil Analisi 2017

Tabel 4. Intensitas pertemuan dalam organisasi kemasyarakatan

\begin{tabular}{|c|c|c|c|c|}
\hline Intensitas pertemuan & $\begin{array}{c}\text { Kalitengah } \\
\text { Lor }(\%)\end{array}$ & $\begin{array}{l}\text { Dusun } \\
\text { Kalitengah } \\
\text { Kidul (\%) }\end{array}$ & $\begin{array}{c}\text { Srunen } \\
(\%)\end{array}$ & $\begin{array}{l}\text { Total } \\
(\%)\end{array}$ \\
\hline Seminggu sekali & 2,9 & 5,1 & 38,6 & 13,9 \\
\hline Sebulan dua kali & 61,8 & 23,1 & 22,7 & 40,4 \\
\hline Sebulan satu kali & 25,0 & 66,7 & 6,8 & 30,5 \\
\hline lainnya & 10,3 & 5,1 & 31,8 & 15,2 \\
\hline Total & 100 & 100 & 100 & 100 \\
\hline
\end{tabular}

Sumber: Hasil Analisis 2017

Dari Tabel 2. menunjukkan bahwa persentase tingkat pendidikan responden di daerah penelitian didominasi tamatan Sekolah Dasar (SD) yaitu sebesar 43 persen, selanjutnya tidak sekolah dan tidak tamat SD masing-masing sebesar 18,5 persen dan 17,9 persen. Jika dibandingkan ketiga dusun penelitian, Dusun Kalitengah Lor mempunyai tingkat pendidikan yang paling rendah. Ada 92,6 persen tingkat pendidikannya tamat SD ke bawah. Dusun Srunen merupakan dusun yang mempunyai tingkat pendidikan yang relatif lebih baik dibandingkan dengan kedua dusun di daerah penelitian. Hampir 60 persen responden tingkat pendidikannya tamat SD ke bawah, namun ada 11,4 persen responden yang tingkat pendidikannya sudah mencapai jenjang perguruan tinggi. Dilihat dari letak geografisnya Dusun Kalitengah Lor terletak paling atas dan dekat dengan puncak Gunung Merapi, sementara Dusun Srunen terletak paling bawah. Semakin ke atas aksesibilitas untuk menjangkau pendidikan semakin rendah.

\subsubsection{Interaksi Sosial}

Identifikasi variable interaksi sosial bertujuan untuk mengetahui apakah variable interaksi sosial mempunyai hubungan atau tidak dengan tetap 140 menetapnya responden di kawasan rawan bencana tersebut. Responden yang ikut dalam suatu perkumpulan atau organisasi kemasyarakatan akan merasa kondisinya tidak rentan dibanding dengan mereka yang tidak sama sekali ikut dalam perkumpulan atau organisasi kemasyarakatan yang ada di lingkungan tempat tinggalnya, karena seseorang yang ikut dalam perkumpulan di lingkungan tempat tinggalnya akan merasa lebih nyaman, tenteram, dan mempunyai hubungan interaksi yang baik dengan lingkungannya.

Berdasarkan hasil survei, semua responden menjawab bahwa di lingkungan tempat tinggal mereka terdapat organisasi kemasyarakatan seperti arisan, kumpulan rembug warga ataupun pengajian. Namun, tidak semua responden mengikuti perkumpulan/organisasi sosial. Seperti apa komposisi responden yang mengikuti perkumpulan ataupun tidak dapat dilihat pada Tabel 3.

\subsubsection{Ikatan Sosial}

Dari hasil analisis tentang ada tidaknya kerabat yang tinggal masih dalam satu lokasi dengan responden, terlihat bahwa ikatan sosial mereka cukup tinggi. Mereka memiliki kerabat yang tinggal masih dalam satu lokasi, 92,7 persen responden menyatakan hal 
itu. Hal ini memungkinkan mereka akan tetap tinggal di Kawasan Rawan Bencana. Sementara itu sebanyak 7,3 persen responden yang tidak memiliki kerabat yang masih dalam satu lokasi, terbanyak di Dusun Srunen kemudian Kalitengah Lor dan Kalitengah Kidul.

Hubungan kekerabatan ini diperkuat juga dari tanah dan rumah tinggal yang mereka tempati. Sebanyak 94,7 persen responden menyatakan tanah dan tempat tinggal yang sekarang ditempati adalah warisan orang tua dan sudah bersertifikat. Mereka menempati tanah sejarah tinggalan dari nenek moyang, maka tanah yang dimiliki harus rela untuk dibagi dengan saudara yang lainnya. Hal ini yang menjadikan hubungan kekerabatan di wilayah ini sangat kental sekali. Dengan adanya sanak saudara yang berada di dekat mereka, menjadikan masyarakat merasa nyaman dan betah tinggal di wilayah yang masuk dalam kategori Kawasan Rawan Bencana III Merapi.

Modal sosial dapat berfungsi sebagai bentuk asuransi informal dan bantuan timbal balik untuk masyarakat, membantu mereka pulih dari kejadian seperti bencana, dan meningkatkan kemungkinan mereka akan merespons secara efektif (Sanyal and Routray, 2016). Penelitian Lalone (2012) di pedesaan Appalachian Virginia mengungkapkan bahwa dengan modal sosial yang kuat dapat memulihkan dengan cepat keadaan masyarakat akibat bencana tornado, terutama pada hari-hari dan minggu-minggu pertama setelah bencana

\subsubsection{Faktor Ekonomi}

Pada umumnya penduduk di daerah penelitian bermatapencaharian utama sebagai petani yaitu sebesar 66,9 persen, penambang pasir sebesar 12,6 persen dan peternak sebesar 6 persen. Namun demikian, ketiga jenis pekerjaan tersebut dapat menjadi pekerjaan sampingan responden. Sebagai contoh responden yang pekerjaan utamanya sebagai petani mempunyai pekerjaan sampingan sebagai peternak ataupun penambang pasir, begitu sebaliknya. Dari 151 responden terdapat 102 responden yang mempunyai pekerjaan sampingan. Berdasarkan hasil survei, pekerjaan sampingan tertinggi yaitu sebagai peternak sebesar 46,1 persen, kemudian diikuti pekerjaan sebagai penambang pasir dan petani, masing-masing sebesar 28,4 persen dan 10,8 persen. Lokasi Pekerjaan, bertujuan untuk mengetahui apakah pekerjaan seseorang bergantung dengan lokasi yang rawan terhadap bencana atau tidak. Seseorang yang mempunyai pekerjaan yang bergantung dengan lokasi yang ia tempati dan rawan bencana akan lebih rentan terhadap bencana tersebut. Sebaliknya, seseorang yang pekerjaannya tidak berada atau tidak bergantung dengan lokasi yang rawan bencana tidak akan rentan terhadap bencana tersebut, sehingga, dimungkinkan seseorang yang bekerja diluar lokasi yang rawan bencana akan memilih tempat tinggal yang lebih aman. Hasil penelitian menunjukkan bahwa 96 persen responden bekerja masih dalam satu lokasi di daerah rawan bencana ini.

Pendapatan merekapun dirasa mencukupi. Hasil analisis menunjukkan sebanyak 56,9 persen penduduk di ketiga dusun tersebut mempunyai pendapatan lebih besar dari UMR Kabupaten Sleman (Tabel 6). Ada sebanyak 43 persen di bawah UMR. Jika dibandingkan dengan ketiga dusun tersebut, Kalitengah Kidul mempunyai pendapatan yang lebih baik dari dua dusun yang lainnya. Pendapatan ini diperoleh dari matapencaharian yang bervariasi.

Tabel 5. Hubungan kekerabatan responden

\begin{tabular}{crrrr}
\hline \multirow{2}{*}{$\begin{array}{c}\text { Mempunyai kerabat di } \\
\text { satu lokasi }\end{array}$} & $\begin{array}{c}\text { Kalitengah } \\
\text { Lor (\%) }\end{array}$ & $\begin{array}{c}\text { Kalitengah } \\
\text { Kidul (\%) }\end{array}$ & $\begin{array}{c}\text { Srunen } \\
(\%)\end{array}$ & $\begin{array}{c}\text { Total } \\
(\%)\end{array}$ \\
\hline Ya & 92,6 & 97,4 & 88,6 & 92,7 \\
Tidak & 7,4 & 2,6 & 11,4 & 7,3 \\
Total & 100 & 100 & 100 & 100 \\
\hline
\end{tabular}

Sumber: Hasil Analisis 2017

Tabel 6. Tingkat pendapatan masyarakat

\begin{tabular}{lrrrr}
\hline \multicolumn{1}{c}{ Pendapatan } & $\begin{array}{c}\text { Dusun } \\
\text { Kalitengah } \\
\text { Lor (\%) }\end{array}$ & $\begin{array}{c}\text { Kalitengah } \\
\text { Kidul (\%) }\end{array}$ & $\begin{array}{c}\text { Srunen } \\
(\%)\end{array}$ & $\begin{array}{c}\text { Total } \\
(\%)\end{array}$ \\
\hline$<1,4$ juta & 44,1 & 33,3 & 50 & 43 \\
1,4 juta $-4,5$ juta & 55,9 & 59 & 45,5 & 53,6 \\
$>4,5$ juta & 0 & 7,7 & 4,5 & 3,3 \\
\hline
\end{tabular}

Sumber: Hasil Analisis 2017.

\section{Kesimpulan}

Faktor Lingkungan meliputi kesuburan tanah, melimpahnya sumber daya mineral terutama pasir, kerikil, dan batu. Kesuburan tanah ditandai dengan tumbuhnya tanaman-tanaman palawija, sayuran, dan tanaman rumput untuk pakan ternak. Sementara, untuk tambang pasir, kerikil, dan batu telah menjadi matapencaharian pokok dan tambahan sebagian masyarakat yang tinggal di daerah penelitian. 
Faktor sosial mempengaruhi masyarakat untuk tetap tinggal di daerah rawan bencana. Adanya ikatan sosial yang tinggi yang ditandai dengan 92,7\% masyarakat di daerah penelitian mempunyai hubungan kekerabatan, 94,7 persen tanah yang mereka tempati adalah tanah warisan dan 95,4\% masyarakat ikut aktif dalam organisasi seperti arisan, pengajian dan perkumpulan lainnya.

Faktor ekonomi diukur dari pendapatan masyarakat. Sebanyak 56,9 persen penduduk di daerah penelitian mempunyai pendapatan lebih besar dari upah minimum regional Kabupaten Sleman 2017 yaitu di atas 1,4 juta rupiah.

\section{DAFTAR PUSTAKA}

Alzwar, M., H. Samodra., dan JJ. Tarigan. (1988).Pengantar Dasar Ilmu Gunung api. Bandung: Nova

Badan Pusat Statistik. (2011). Hasil Sensus Penduduk 2010, BPS.

BAPPENAS dan BNPB.(2011). Rencana Aksi Rehabilitasi dan Rekonstruksi Wilayah Pasca Bencana Erupsi Gunung Merapi di Provinsi D.I. Yogyakarta dan Provinsi Jawa Tengah Tahun 2011-2013. Jakarta: Bappenas dan BNPB.

Davidson, J. and Da Silva, S.(2000). Composite volcanoes. In: Sigurdsson, H. (ed) Encyclopediaof Volcanoes. Academic Press.

Herianto, Ageng S dan Drajat Wicaksono. (2012). "Sosialisasi dan Negoisasi Proses Relokasi Pengungsi Korban Erupsi Merapi Di Cangkringan Yogyakarta Upaya Pengurangan Potensi Konflik" Kajian Multidisiplin: Sumbangan Pemikiran SekolahPascasarjana Universitas Gadjah Mada Bagi Korban Erupsi MerapiTahun 2010. Yogyakarta: Sekolah Pascasarjana UGM.

Himbawan, Gigih. 2010. Penyebab Tetap Bermukimnya Masyarakat Di Kawasan Rawan Bencana Kelurahan Tanjung Agung Kota Bengkulu. Magister Teknik Pembangunan Wilayah dan Kota. Program S-2, Fakultas Teknik Pembangunan Wilayah dan Kota Universitas Diponegoro.

LaLone, M. B. (2012). Neighbors Helping Neighbors: An Examination of the Social Capital Mobilization Process for Community Resilience to Environmental Disasters. Journal of Applied Social Sciences, 6(2), 209-237.

Magnis, F. (2003). Etika Jawa : sebuah analisa falsafi tentang kebijaksanaan hidup Jawa. Jakarta : Gramedia Pustaka Umum.

Mawardi, (2006). Rencana Aksi Nasional Pengurangan Risiko Bencana 2006-2009. Kerjasama antara Kementrian Negara Perencanaan Pembangunan Nasional/Badan Perencanaan Pembangunan Nasional dengan Badan Koordinasi Nasional Penanganan Bencana. Jakarta.

Ni'am, L. (2014). Kepengaturan dan Penolakan Relokasi:Kasus Warga Watugajah Pasca bencana Gunung MerapiTahun 2011-2013. Jurnal Ilmu Sosial dan Ilmu Politik Volume 18, Nomor 1, Juli 2014 (196).

Pemerintah Desa Glagaharjo. (2016). Data Monografi Desa Glagaharjo Kecamatan Cangkringan Kabupaten Sleman Semester Pertama Tahun 2016.
Pratomo, I. and Abdurachman, K. (2004). Characteristics of the Indonesian active volcanoes andtheir hazards. Mineral \& Energi, 2, no. 4, h. 56-60.

Rijanta, R; Hizbaron, Baiquni, M. (2014). Modal Sosial dalam Manajemen Bencana. Yogyakarta: Gadjah Mada University Press.

Subandriyo, (2012). Ancaman Gunung Merapi Pasca Erupsi 2010 Berdasarkan Hasil Permodelan Awan Panas dan Lahar untuk Mendukung Rencana Tata Ruang/Wilayah Berbasis Mitigasi Bencana, Proceeding Seminar Nasional Konsep Hidup Harmonis Bersama Risiko Bencana di Hotel Inna Garuda Yogyakarta tanggal 25 Mei 2012, Yogyakarta.

Sanyal, S and Routray, J. (2016). Social Capital and Disasters: Analysis of cases with field evidences. International Conference on Disaster Management: From Polar Region to the Local Communities Social and Environmental Development National, Institute of Development Administration (NIDA).

Thouret, J.C., Lavigne, F., Kelfoun, K., Bronto, S. (2000). Toward Revised Hazard Assessment atMerapi Volcano, Central Java. Journal of Volcanology and Geothermal Research Volume 100(2000), Elsevier, Amsterdam, hal. 479-502.

Triyoga, S. (2010). Merapi dan Orang Jawa: Persepsi dan Kepercayaannya. Jakarta: PT Gramedia Widiasarana Indonesia.

Voight, B., Constantine, E.K., Siswowidjoyo, S., Torley, R., 2000. Historic al Eruptions of Merapi Vocano, Central Java, Indonesia,1768-1998. Journal of Volcanology and Geothermal Research Volume 100 (2000), Els evier , Amsterdam, ha l. 69-138.

Yusup, Y. (2014). Hidup Bersama Risiko Bencana: Konstruksi Ruang dalam Perspektif Ruang Relasional. Jurnal Perencanaan Wilayah dan Kota, vol.25, no. 1, hlm. 59-77. 